\title{
Soft Law Engagements and Hard Law Preferences: Comparing EU Lobbying Positions between UN Global Compact Signatory Firms and Other Interest Group Types
}

\author{
Ms. Onna van den Broek* \\ ${ }^{\star}$ Corresponding author: Onna van den Broek, Political Economy, King's College London, London, United Kingdom; \\ Email: onna.van_den_broek@kcl.ac.uk
}

\begin{abstract}
Although corporate social responsibility (CSR) has gone "mainstream," the relationship between CSR and corporate political activities (CPA) has received little scholarly attention. This is problematic because firms potentially have a more sizable impact through their lobbying activities for socially and environmentally beneficial (or unbeneficial) public policies than through their own operations. This paper investigates if, and how, UN Global Compact signatory firms differ in their policy preferences on key EU proposals compared to other interest groups. To capture state-of-the-art data on firms' policy preferences, I draw from the INTEREURO database, which includes firms' lobbying positions on forty-three directives and twenty-seven regulations covering 112 public policy issues in the European Union. Statistical results show that Global Compact signatory firms significantly lobby for stricter regulation than non-signatory firms and industry associations, however, their positions are still lower than nonbusiness groups. These results are similar across various public policy issues and suggest that the regulatory preferences of firms' participating in soft law CSR initiatives are more aligned with stakeholders' interests. This paper contributes to public policy literature exploring the relationship between hard and soft law as well as literature studying the political representation of divergent interest.
\end{abstract}

Keywords: corporate social responsibility (CSR); corporate political activities (CPA); lobbying; public policy; UN Global Compact

\section{Introduction}

"We still see a widespread disconnect between businesses' aspirations towards responsible corporate citizenship and their own lobbying efforts. It is precisely this lack of consistency that can undermine the credibility of corporate responsibility and diminish its benefits. For the Global Compact, corporate lobbying is thus naturally a key issue." 1

\section{-Georg Kell, first executive head of the UN Global Compact}

Although corporate social responsibility (CSR) has gone "mainstream," the effect of CSR on business support for regulatory changes has received little scholarly attention. As can be deduced from Georg Kell's comment, this is problematic because firms potentially have a more sizable impact through their lobbying activities for socially and environmentally beneficial (or unbeneficial) public policies than through their own operations. ${ }^{2}$ The misalignment and discrepancy between the two is illustrated by BP, a British multinational oil and gas company, which is one of the founding companies of the Global Compact. In their 2018 sustainability report they claimed to "help support the expansion of carbon pricing,"3 while they simultaneously contributed to a lobbying campaign that successfully blocked carbon tax policy in Washington state. ${ }^{4}$

\footnotetext{
${ }^{1}$ AccountAbility and Global Compact 2005, 1.

${ }^{2}$ Lyon et al. 2018.

${ }^{3} \mathrm{BP} 2018$.

${ }^{4}$ Influence Map 2020.

( ) The Author(s), 2021. Published by Cambridge University Press on behalf of V.K. Aggarwal. This is an Open Access article, distributed under the terms of the Creative Commons Attribution licence (http://creativecommons.org/licenses/by/4.0/), which permits unrestricted re-use, distribution, and reproduction in any medium, provided the original work is properly cited.
} 
Scholarly work that has examined the relationship between CSR and corporate political activities (CPA), has largely focused on intraorganizational resource trade-offs, such as trust, reputation, and legitimacy. ${ }^{5}$ In addition, the few studies that do look at CSR and regulatory preferences have presented conflicting results. Almost a decade ago, Gjølberg argued in Business and Politics that Nordic firms with strong CSR performances are skeptical about voluntary initiatives and prefer stricter international regulation of social and environmental issues. ${ }^{6}$ Tellingly, Nordic countries tend to have higher levels of institutionalization, and systematic embeddedness, of CSR policies in national governance. ${ }^{7}$ Recently, Kinderman has refuted Gjølberg's finding by studying the role Nordic governments, business associations, and companies played in the negotiations over the European Union's corporate transparency Directive 2014/95/EU. They found that Nordic countries have strong CSR performances, however, this did not translate into strong support for more stringent regulation. ${ }^{8}$

Providing further empirical clarity on the relationship between CSR and policy preferences follows the recent call for more "impact-driven" CSR research. ${ }^{9}$ My aim is to advance empirical testing on four sampling and methodology related issues. First, this article focusses explicitly on the Global Compact, a classic but highly debated CSR initiative. ${ }^{10}$ Second, it enlarges the geographical scope, which allows me to focus on firm-level-differences. Third, the paper marks a methodological advance on existing studies by being both policy specific as well as encompassing a broader array of policies-rather than solely focusing on corporate accountability policies-in a quantitative manner. Fourth, it attempts to capture a more thorough picture of lobbying by gathering firms' policy preferences directly from policymakers instead of focusing on third-party data or self-identified policy positions, which are common approaches in existing studies.

To this end, I use the INTEREURO database for which ninety-five structured interviews were conducted within the European Commission (EC) to determine interest groups' lobbying efforts on fortythree directives and twenty-seven regulations covering 112 policy issues in the European Union between 2008 and 2010. Interviewees situated interest groups' policy preferences on a 100-point scale, with 100 indicating the strongest degree of support for more stringent EU regulation and 0 the lowest degree of support. Statistical analyses show three key findings. First, firms that are signatories to the Global Compact lobby significantly for more stringent regulation than non-signatory firms and industry associations. Second, even though signatory firms are more aligned with nonbusiness groups' preferences compared to other business interest groups, they still prefer significantly less regulatory change. Third, the differences between the four interest group types materialize across social, environmental, and economic policy domains. Hence, I provide tentative evidence that Global Compact signatory firms prefer more regulation and are more aligned with stakeholders' interests than other firms and business groups.

The empirical questions that motivated this research theoretically contribute to two core debates in scholarship situated at the intersection between business and politics. First, this study is adjacent to scholarship examining the continuum, and relationship, between hard and soft law constellations in international business regulation. ${ }^{11}$ More specifically, corporate positions towards EU directives and regulation are attempts to influence hard law, whereas participation in the Global Compact depicts a soft law arrangement. Together, they are part of a "smart-mix" of policy tools. There have been various calls for more scholarly work on the relationship between voluntary initiatives and hard law. ${ }^{12}$ By studying Global Compact participation, I weigh in on scholarly debates about the ethical behavior of

\footnotetext{
${ }^{5}$ Den Hond et al. 2014; Liedong et al. 2015; Wang and Qian 2011; Lock and Seele 2016. There are a few exceptions, such as the work of Anastasiadis (2014).

${ }^{6}$ Gjølberg 2011.

${ }^{7}$ Knudsen, Moon, and Slager 2015.

${ }^{8}$ Kinderman 2019.

${ }^{9}$ Barnett et al. 2020.

${ }^{10}$ Schrempf-Stirling 2018, 3; De Bakker, Rasche, and Ponte 2019, 346.

${ }^{11}$ Abbott and Snidal 2000; Dashwood 2017; Kinderman 2016; Kirton and Trebilcock 2017; Rasche 2015; Schrempf-Stirling 2018; Shaffer and Pollack 2009.

${ }^{12}$ Rasche and Waddock 2014, 214; Kirton and Trebilcock 2017.
} 
firms that are signatories of the Global Compact compared to non-signatories. As such, this paper extends previous literature treating corporate policy preferences as an indicator of strengthened responsibility.

Second, this paper dovetails with scholarship on the political representation of divergent interests, which lies at the core of theories on power and government. ${ }^{13}$ One type of interest group that arguably has unequal access and power over policymaking are actors representing economic interests. ${ }^{14}$ The significance of this privileged business access is dependent upon the degree of preference alignment with the public good. Nonbusiness groups are oftentimes assumed to represent stakeholders' interests. Thus, by comparing the regulatory stringency preferences between business and nonbusiness interest groups, I am able to infer conclusions about how Global Compact signatories' interests are more or less in agreement with the broader stakeholders' interests, without having to make a normative evaluation of what constitutes "good policy."

\section{Theoretical framework and hypotheses}

Global business regulation operates on a continuum between hard and soft law. ${ }^{15}$ Hard law, on the one hand, refers to "legally binding obligations that are precise [..] and that delegate authority for interpreting and implementing the law." They depend on "formally mandated participation and regularly assessed obligatory contributions, organization, resources, and sanctions of the institution itself."16 Numerous interest groups, such as industry associations, citizen groups, and firms, attempt to influence officials in order to achieve policy outcomes favorable to them. ${ }^{17}$ Business actors are particularly well positioned to shape regulation through their lobbying activities ${ }^{18}$ as a result of their ability to convert economic power into politically relevant resources as well as their increased "exit power" over investments. ${ }^{19}$ Corporate lobbying is anchored in firms' preferences, and corresponding lobbying positions, to shape public policies in a specific direction. Presumably, this is driven by material and instrumental concerns about profit maximization.

Soft law, on the other hand, has less stringent degrees of obligation, precision, or delegation and depends on "voluntarily supplied participation, resources, and consensual actions of their members." 20 These arrangements oftentimes have a global or transnational character and focus on the failings of market mechanisms, such as environmental degradation..$^{21}$ They rely on the participation of nongovernmental actors and can roughly be divided in voluntary business standards and (informal) institutions, ${ }^{22}$ also known as principle-based multi-stakeholder initiatives. Both have the potential to pave the road, or function as a "stepping-stone," to hard law efforts. ${ }^{23}$ A classic example of such a soft law institution is the Global Compact, ${ }^{24}$ which relies on voluntary business participation to help meet the UN goals. The United Nation's mission is to develop a consensus on shared values and global norms that will guide, and transform, the global economy by way of their visibility, global reach, universality, neutrality, and conveying power. ${ }^{25}$

Despite the significance of the choices corporations make between hard and soft law arrangements, there is limited empirical knowledge on how they are linked. ${ }^{26}$ The key empirical question of this paper

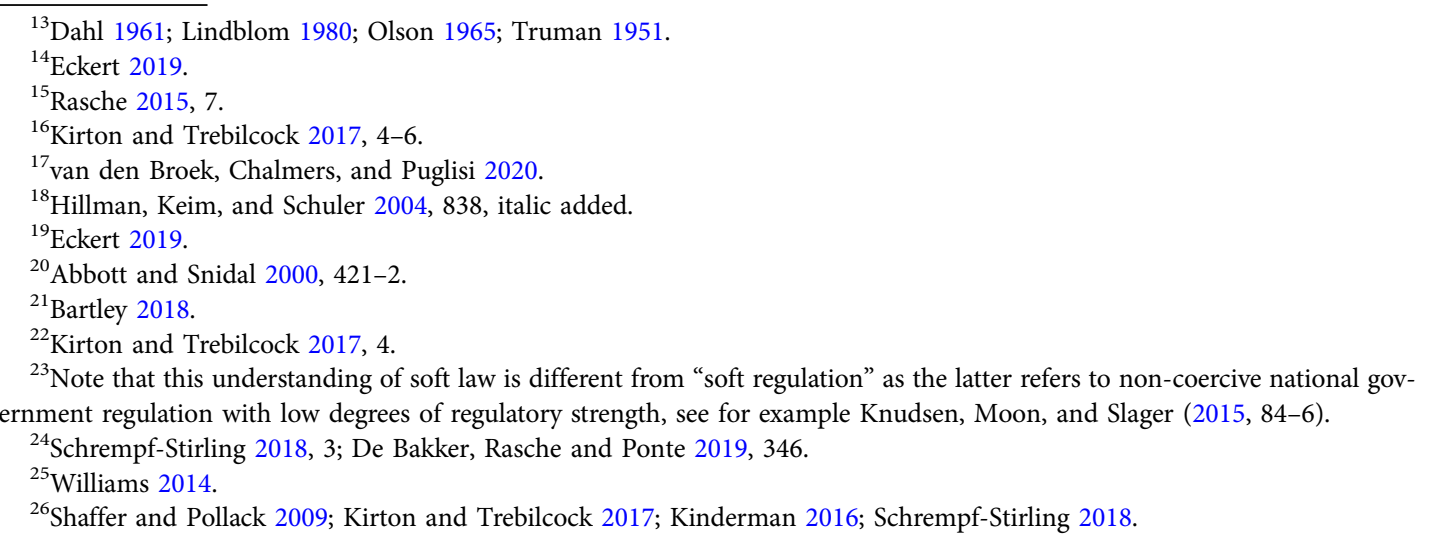


is if, and how, Global Compact signatories differ in their policy preferences compared to other interest groups. The emphasis on "other interest groups" as opposed to solely "non-signatory firms" allows for cross-group comparison and strengthens the ability to draw conclusions on the political representation of divergent interests. ${ }^{27}$ To hypothesize this relation, the first step is to elaborate what the Global Compact is, and what it is not. There has been a lively scholarly debate on how effective and legitimate this soft law initiative is, with the primary point of theoretical friction being its broader purpose. ${ }^{28}$

On the one hand, scholars have critically appraised the Global Compact as an overall failure. The lack of compliance mechanisms and the scattered focus prompts Sethi and Schepers to conclude that the Global Compact has become a "a dry bed of sand." To elaborate, as a result of low entry barriers, adverse selection takes place, meaning that "the companies with the worst track record would be quite interested in joining the group at the first opportunity to enhance their otherwise poor reputation by publicizing their group membership." Combine this with little monitoring or compliance mechanisms, and firms are able to "free-ride," put differently, to get the benefits of joining without putting in any work. ${ }^{29}$ This is supported by empirical work that finds that Global Compact signatory firms are able to enjoy the benefits of membership without implementing any costly changes to their human rights and environmental practices. ${ }^{30}$

On the other hand, scholars have weighed the Global Compact as an overall success. Rasche and Waddock responded to Sethi and Schepers by rightly pointing out that the Global Compact should be understood as a principle and learning-based network rather than a monitoring, accrediting, and enforcement vehicle. ${ }^{31}$ The low entry barriers are, therefore, perceived as a positive; the aim of the sociologic institutional design is for companies with a poor track record to join and improve their performance via mechanisms of norm diffusion, persuasion, and learning. ${ }^{32}$ Hence, group dynamics are alike to most other types of networks, in which membership incites processes of organizational learning and socialization. Through participation, normative rules about firm behavior are defined and disseminated, providing a vehicle for isomorphism. ${ }^{33}$ This can stimulate broader public policies by creating shared norms and understanding of what responsible business conduct constitutes. ${ }^{34}$

Additionally, the Global Compact was designed as a "means to serve as a (frame) of reference to stimulate best practices and to bring about convergence around universally shared values." 35 As such, it can best be understood as a very loose soft law arrangement ${ }^{36}$ that brings "together the proliferating international rules of the game" and "can provide a space for argumentative persuasion." 37 Its embeddedness in the UN system helps to justify a common moral basis to promote universal norms and create cross-cultural acceptance. ${ }^{38}$ Thus, by expanding the amount of signatories, a critical mass can be reached that helps develop a consensus on the global business norm of social responsibility. ${ }^{39}$ Schembera shows that the duration of participation in the Global Compact positively affects the levels implementation and, hence, provides empirical support for the evolutionary and learning character of the Global Compact.

The next logical step is to combine this knowledge on the Global Compact with insights on how firms define their individual policy preferences. Generally, business is regarded as a homogenous actor, lobbying for less stringent or lower levels of regulation. Dür et al., in their seminal study, present empirical support for these claims by measuring interest conflicts within business. They find that

\footnotetext{
${ }^{27}$ Truman 1951; Olson 1965; Lindblom 1980.

${ }^{28}$ Voegtlin and Pless 2014, 179.

${ }^{29}$ Sethi and Schepers 2014, 196, 207.

${ }^{30}$ Berliner and Prakash 2015.

${ }^{31}$ Rasche and Waddock 2014, 210.

${ }^{32}$ Berliner and Prakash 2014, 2019-220; Shaffer and Pollack 2009, 708.

${ }^{33}$ Brammer et al. 2012, 16; DiMaggio and Powell 1983.

${ }^{34}$ Gjølberg 2011; Daswood 2017; Schrempf-Stirling 2018, 11.

${ }^{35}$ Kell and Ruggie 1999, 11; see also, Ruggie 2007.

${ }^{36}$ Gjølberg 2011, 4.

${ }^{37}$ Dashwood 2017, 197-8.

${ }^{38}$ De Bakker, Rasche, and Ponte 2019, 361.

${ }^{39}$ Williams 2014, 248.
} 
businesses' interests and priorities often align in the European Union as firms strongly mobilize to protect the status quo and, consequently, seek to kill or weaken new regulatory mandates. ${ }^{40}$ The underlying logic is that public policies already reflect corporate preferences and implementing regulatory changes is very costly. ${ }^{41}$ This is supported by the lobbying positions of industry associations. These groups aggregate business members' viewpoints in an attempt to "speak with one voice" and, as such, often seek the "lowest common denominator of consensus." ${ }^{\text {" }}$ "They are known to lobby officials for a reduction of the regulatory burden on a particular industry. ${ }^{43}$

A regulatory race to the bottom, or a lock-down of the status quo, is assumed to counter the public interest. ${ }^{44}$ This is illustrated by the fact that interest groups that claim to represent citizens, and thus stakeholders' interests, lobby for more stringent types of regulation than other interest groups. ${ }^{45}$ If Global Compact signatory firms' preferences are more aligned with the stakeholders' interest, we would expect them to lobby for more stringent regulation and that their preference significantly differ from industry association but not be significantly different from nonbusiness interest groups. Indeed, there are various examples where individual firms and nonbusiness interest groups' preferences converged, complementary political goods were identified, and ad-hoc political partnerships were created. In the case of the Danish bottle standards, for example, higher environmental standards also enacted as a nontariff barrier leverages, resulting in a collaboration between individual firms and nonprofit groups. ${ }^{46}$ This leads to the first two hypotheses:

\section{Hypothesis 1: Global Compact signatory firms prefer the same stringency of policy change as citizens groups.}

Hypothesis 2: Global Compact signatory firms prefer more stringent policy change than industry associations.

The deviation from defending the status-quo also alludes to heterogenous business preferences. Hence the next question is, "what are the conditions under which some companies sign on to far-reaching government solutions when others reject them?" 47 Firstly, Global Compact signatory firms may have different institutional capacities and pressures. Most relevant, seminal work by Martin found that firms that have stronger internal capacity for policy evaluation and are connected to external networks are more likely to push for stricter regulation. ${ }^{48}$ Global Compact membership signals both: Signatories are likely to be better able to grasp and support complicated social issues due to heightened knowledge $^{49}$ and the Global Compact's institutional set up links the individual firm to a larger community of policy ideas. Iterated interactions will even cause signatory firms to become more similar in norms, habits and beliefs over time, resulting in an ideational convergence of regulatory preferences. ${ }^{50}$ Firms genuine in their attempts to improve social and environmental conditions may realize that if they want other firms to behave in similar ways, the most efficient way is to put hard laws in place so that the same rules apply to all. ${ }^{51}$ As a result, Global Compact signatory firms are more likely to recognize regulation as a supportive measure for the (voluntary) development of their CSR agenda. ${ }^{52}$

Furthermore, firms mostly support regulatory races to the top as a result of their competitive advantages. To illustrate, imagine a firm which already adheres to stricter rules. Cementing these rules into

\footnotetext{
${ }^{40}$ Dür et al. 2019; Kinderman 2016, 41; Kinderman 2019.

${ }^{41}$ Chalmers and Young 2020.

${ }^{42}$ Conzelmann 2012; Schmitter and Streeck 1999.

${ }^{43}$ Barnett 2013.

${ }^{44}$ Karr 2007, 77.

${ }^{45}$ Dür et al. 2015; I infer that if citizens groups prefer more regulatory changes, regulatory stringency is in the stakeholders' interest.

${ }^{46}$ Coen 1998.

${ }^{47}$ Martin (1995).

${ }^{48}$ Ibid.

${ }^{49}$ Den Hond et al. 2014.

${ }^{50}$ Chalmers and Young 2020.

${ }^{51}$ Rivoli and Waddock 2011, 101.

${ }^{52}$ Schrempf-Stirling 2018, 11.
} 
regulation would mean that their competitors are forced to implement costly changes. To provide a practical example, during the EU Basel II Accord, a small group of banks with a competitive advantage in particular risk management techniques sought to make the capital requirements more stringent. ${ }^{53}$ As a result, they raised competitors' costs which yet had to develop similar competencies, whilst they already complied with the newly sought-after rules. ${ }^{54}$ More specifically, Gjølberg finds that firms with a good track-record for CSR have a clear preference for more hard law. Managers in these firms argued that it makes sense strategically for them to lobby for binding regulation as "they most likely already comply with conceivable future regulatory requirements." 55 This logic can be extended to Global Compact signatory firms: If they already adhere to stricter rules around business responsibility, we would expect them to leverage this competitive advantage by lobbying for stricter regulatory changes than non-signatories. This results in the following hypothesis:

Hypothesis 3: Global Compact signatory firms prefer more stringent policy change than non-signatory firms.

Nevertheless, Global Compact membership may not affect all policy issues equally. The CSR concept can be defined as the systematic inclusion of environmental, societal, and governance issues in core business models. ${ }^{56}$ Accordingly, the Global Compact focusses on CSR-related issues, encompassing human rights, labor, environment, and anticorruption. The impact of Global Compact membership may, as a consequence, be limited to certain types of issues. The variation between policy issues provides an useful analytical tool for comparative analysis. Scholars taking a policy sector approach argue that "policy determines politics"; in other words, there is a causal effect of the nature of policies on the regulatory outcomes and options. ${ }^{57}$

Different studies have taken different stances regarding the specific policy issues that are affected by CSR institutions. Kinderman, for example, takes a narrow approach by focusing their study solely on the linkage between CSR institutions and CSR related regulation, specifically the EU nonfinancial directive. ${ }^{58}$ CSR policies can be defined as "those designed to encourage responsible business behavior but not to require it." ${ }^{59}$ Gjølberg, on the other hand, takes a wider approach by studying the effect of CSR on business preferences toward broader social and environmental regulation. ${ }^{6}$ This wider approach responds to the notion that social and environmental policies constrain corporate freedoms as they are seen as regulation of business, whereas economic policies enable corporate activities as they are seen as regulation for business. ${ }^{61}$ Examples of environmental regulation are climate policies, energy transitions, or carbon emission schemes. Social regulation includes social policy, basic rights protection and the provision of public goods, such as health care or education. ${ }^{62}$ Hence, the fourth and last hypothesis introduces policy domain as a moderating variable:

\section{Hypothesis 4: The effect of the hypotheses is stronger for social and environmental policies than for eco- nomic policies.}

\section{Research design}

This article aims to empirically improve on previous studies ${ }^{63}$ dealing with CSR and regulatory preferences in terms of sampling, data collection, and operationalization. First, it broadens the geographical scope beyond Nordic countries whilst focusing explicitly on Global Compact membership. Previous

\footnotetext{
${ }^{53}$ Chalmers and Young 2020, 55-6.

${ }^{54}$ Fremeth and Richter 2011.

${ }^{55}$ Gjølberg 2011, 9, 20.

${ }^{56}$ Visser 2010.

${ }^{57}$ Freeman 1985, 469.

${ }^{58}$ Kinderman 2016; see also Kinderman 2019.

${ }^{59}$ Knudsen, Moon, and Slager 2015.

${ }^{60}$ Gjølberg 2011.

${ }^{61}$ Llewellyn 2007, 181.

${ }^{62}$ Wettstein and Baur 2016.

${ }^{63}$ Most notably, the studies of Gjølberg 2011 and Kinderman 2019.
} 
research has indicated that CSR norms and practices differ per socio-political context ${ }^{64}$ and, as such, expanding firms' country of origins will increase generalizability. However, to control for endogeneity, I opt to focus on one political context, namely the European Union. This provides an empirically interesting case because of the ongoing delegation of legislative responsibilities from member states to EU institutions, which has resulted in a shifting locus of European-level lobbying. ${ }^{65}$ Furthermore, focusing on individual firm participation in a CSR initiative accounts for the fact that CSR as a practice is attributed to individual firms. Although aggregated country-level data is important to explain cross-national variations, ${ }^{66}$ in order to show firm-level variations research must measure both CSR and policy preference on the organizational level.

Second, this article focusses on specific policy proposals while simultaneously covering a wide range of policy issues. Going beyond the inclusion of only corporate accountability policies better captures the full range of firms' lobbying activities and political impacts. Policy specificity is crucial since firms' general sentiments toward hypothetical regulatory stringency cannot capture real-life policy preferences. ${ }^{67}$ Therefore, preferences need to be empirically established for each specific policy proposal, and even then, there is a problem with multidimensional topics, calling for further issue disaggregation. ${ }^{68}$ At the same time, however, policy preferences should be "assessed for a relatively large number of cases. The resulting large- $\mathrm{N}$ studies, if the cases were selected following the appropriate rules, allow for generalizations of the findings." 69 Thus, firms' policy preferences in one policy domain do not necessarily translate into another policy domain, calling for the inclusion of a wide variety of policy issues.

Lastly, this article aims to measure firms' policy preferences as expressed in their lobbying efforts behind closed doors. The general lack of empirical studies examining the interaction between CSR and corporate lobbying stems from the lack of data access. Favotto and Kollman show that most firms are "still reluctant to reveal the positions they take on specific policies and almost never do so when they are trying to block a legislative initiative." ${ }^{70}$ As such, corporate content-analyses, interviews, or surveys may only contain part of the story and, thus, remain one-sided. A more compelling approach is to directly ask policymakers involved in a specific policy proposal to identify actors' policy preferences based on their interactions with these lobbying actors. The state-of-art method to make meaningful comparisons between actors' policy positions is to quantify these preferences spatially, ${ }^{71}$ which I will discuss in the next section.

\section{INTEREURO sample}

The sample for this research was drawn from the large, integrated dataset on lobbying activities in the

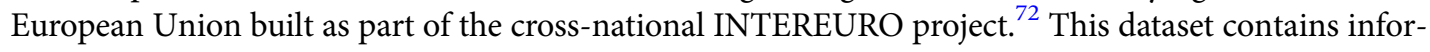
mation on interest groups' lobbying efforts on a stratified random sample of 124 policy proposals put forward by the EC between 1 January 2008 and 31 December $2010 .^{73}$ This sampling method, thus, critically differs from taking all interest groups as the sample population. Since this article is concerned with hard law preferences, only proposals for EU directives and regulations were included. Furthermore, to avoid capturing proposals with limited lobbying activities and little public conflict,

\footnotetext{
${ }^{64}$ Matten and Moon 2008.

${ }^{65}$ Ruggie 2018.

${ }^{66}$ Bernhagen, Mitchell, and Thissen-Smits 2013.

${ }^{67}$ Beyers, Eising, and Maloney 2008.

${ }^{68}$ Chalmers and Young 2020.

${ }^{69}$ Dür 2008.

${ }^{70}$ Favotto and Kollman 2019, 9.

${ }^{71}$ Measuring policy preference in terms of regulatory stringency allows for general measure, however, it is important to note that it washes out nuances, as is discussed in Chalmers and Young (2020).

${ }^{72}$ The INTEREURO dataset is not without complications and difficulties, most notably, the omittance of issues that are kept off the policy agenda as a result of corporate lobbying (see Eckert, 2019) and the difficulty of capturing "true" policy preferences through elite interviews.

${ }^{73}$ For more information on the sampling procedure see Beyers et al. (2014).
} 
Table 1: Sample of policy proposal descriptions

\begin{tabular}{|c|c|c|}
\hline • Alternative investment & $\diamond$ Energy integrity & $\diamond$ Institution powers \\
\hline - Car safety & Emission Trading System & - Light vehicle emissions \\
\hline Carbon capture storage & $\downarrow$ Fake drugs & - Metrology \\
\hline Copyright protection & Fisheries reconstruction & $\checkmark$ Over-the-counter derivatives \\
\hline$\checkmark$ Credit rating agencies & $\diamond$ Marine life & - Petrol vapour recovery \\
\hline Deposit guarantee scheme & Fruit juice & Roaming \\
\hline Duty on biodiesel imports & - Hazardous materials & - Waste Electrical \& Electronic Equipment \\
\hline
\end{tabular}

the sample was stratified according to public saliency, meaning that only proposals that met a minimum level of public visibility were selected, which was operationalized as being mentioned in at least two leading newspapers. ${ }^{74}$ This selection strategy ensures a minimum level of controversy, political salience, and public attention for all policy proposals.

The principle source of data was EC officials due to their centrality within the EU legislative process. More precisely, the EC has the sole right to initiate legislation and is therefore responsible for drafting proposals. ${ }^{75}$ As a result, they are best placed to assess actors' policy positions and place them within the wider legislative context. For each proposal, the lead Directorate General (DG) was identified and interviews were requested with the officials responsible for the proposals. DGs are policy departments within the EC that perform a technical function by developing, implementing, and managing EU policies. Interviewing took place in 2012. This two to four-year lag ensured that most proposals had been adopted during the interviewing stage. Overall, ninety-five structured elite interviews were conducted with policy officers or (deputy) heads of units, lasting on average seventy minutes. For fifty-four proposals access was denied or interviews did not yield enough information.

The final sample contained seventy policy proposals, including forty-three directives and twenty-seven regulations. Both directives and regulations concern generally binding EU law. Proposals that did not change the substance of existing legislation, such as codifications, were not included in the sample. For these proposals, 1043 lobbying efforts were identified, of which there were 651 lobbying efforts by industry associations (41 percent) and 224 lobbying efforts specifically by individual firms (21 percent). ${ }^{76}$ Policy proposals ranged from "consumer labels on fruit juices" to the "classification of chemicals as hazardous materials," and are, thus intentionally broader than solely corporate accountability policies. Table 1 provides a sample of policy proposals. ${ }^{77}$ Furthermore, to make meaningful comparisons, the interviews were based on a structured questionnaire and interviewees were asked to identify three distinct issues that stakeholders disagreed on during the proposal, resulting in ninety-eight policy issues. For example, the policy proposal on "alternative investments" included two policy issues: what types of funds should be regulated and whether this should be open to third countries.

\section{Dependent variable: business policy preference}

To quantify policy preferences (P), and make meaningful comparisons, officials were asked to identify which interest group actor(s) actively lobbied on each policy proposal and estimate their positions. Each actor was located on an "issue continuum ranging from 0 to 100, where 0 means least support for EU regulation and the higher values indicate support for more regulation." ${ }^{78}$ The higher the value,

\footnotetext{
${ }^{74}$ To focus solely on relevant lobbying entries within the INTEREURO dataset, I use the sampling methods as per the seminal work of Dür et al. (2019).

${ }^{75}$ Bouwen 2004.

${ }^{76}$ This includes 98 unique firms as some actors were active on several issues.

${ }^{77}$ Policy proposals were picked along the following criteria: interest group activity $(\mathrm{N}>10)$ and lobbying activities by individual firms $(\mathrm{N}>1)$.

${ }^{78}$ Dür et al. 2019, 25.
} 


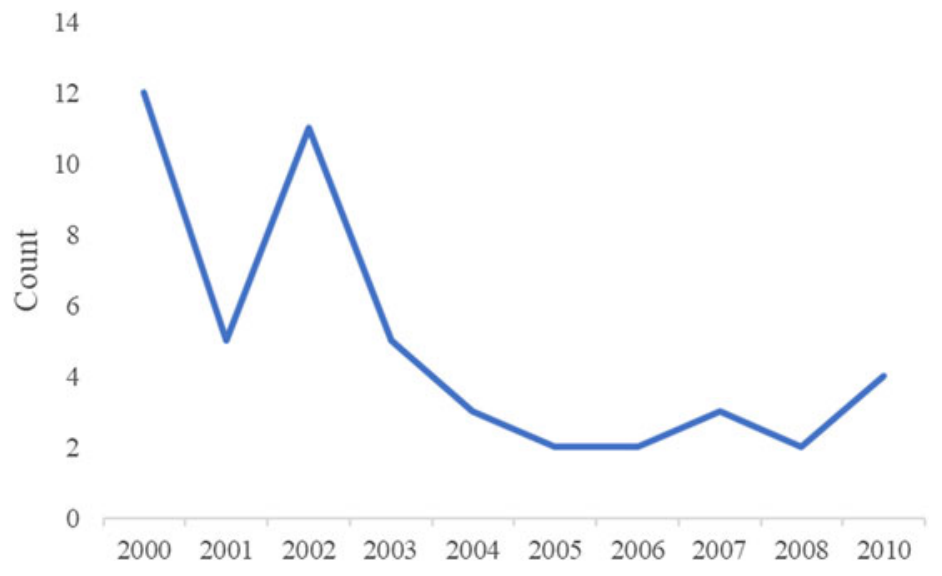

Figure 1: Number of sampled firms joining the Global Compact, per year

the more stringent regulatory change an actor preferred. Actors who held the most extreme positions were placed on either end of the issue continuum before all other actors were located. In addition, officials were asked to identify the policy preferences of the EC, the Council, the European Parliament (EP), party groups in the EP, and member states that took a clear position. Lastly, officials were asked to locate the reversion point (RP), the position if no agreement would be found, often equal to the status quo. All information was supplemented and cross-checked by a content analysis of 251 position papers. In addition, I created an ordinal measurement of preference to calculate the probabilities of being extremely conservative or progressive; where $\mathrm{P} \leq 10$ was recoded as preferring a continuation of the status quo, $10<\mathrm{P}<90$ as preferring slightly more stringent regulation and $\mathrm{P} \geq 90$ as preferring substantively more stringent regulation. ${ }^{79}$

\section{Independent variable: global compact signatory firms}

For each individual firm, I determined whether they were a signatory member of the Global Compact. This data is policy proposal specific; this means that if the proposal has been put forward by the EC in 2008, firms had to be a signing member by that year. The data collected on Global Compact membership informed the variable "interest group types," dividing the sample into four categories: "signatory firms," "non-signatory firms," "industry associations," and "non-business groups." 80 Comparisons between these groups is pivotal in this study and, as such, the final sample includes both signatory and non-signatory firms. This approach has the advantage of being able to discover and unfold differences between interest groups types. However, since certain characteristics make firms more likely to join the Global Compact, in other words firms are not randomly assigned to these groups, ${ }^{81}$ caution toward causal claims is exercised. As such, the results aim to demonstrate that Global Compact signatory firms perform differently in relation to non-signatory firms, but do not seek to make any causal claims on whether signatory firms "improve their performance after joining the CSR club with respect to their performance before they joined it." ${ }^{\prime 2}$

Overall, forty-three firms in the sample were not a signatory member of the Global Compact as of end 2010, marking the last policy proposal included in this study. Four sampled firms were delisted during this period as a result of the ban on tobacco firms, noncommunication, misconduct, or upon individual request. Of the thirty-nine firms that joined the Global Compact before the end of

\footnotetext{
${ }^{79}$ The preferability between the two, however, depends heavily on political outlooks. Both have a procedural and substantive character, which may vary in the "eye of the beholder."

${ }^{80} \mathrm{By}$ include business associations as an additional categorical groups, I respond directly to Kinderman's (2019) concern about the role of industry associations.

${ }^{81}$ Schembera 2018, 788.

${ }^{82}$ Berliner and Prakash 2014, 222.
} 
Table 2: Active policy issues (amount) by policy domain and interest group type

\begin{tabular}{lccccc}
\hline & $\begin{array}{c}\text { Global } \\
\text { Compact } \\
\text { firms }\end{array}$ & $\begin{array}{c}\text { Non-signatory } \\
\text { firms }\end{array}$ & $\begin{array}{c}\text { Industry } \\
\text { Associations }\end{array}$ & $\begin{array}{c}\text { Non-business } \\
\text { groups }\end{array}$ & $\begin{array}{c}187 \\
\text { Total }\end{array}$ \\
\hline $\begin{array}{l}\text { Social and } \\
\text { Environmental } \\
\text { issues }\end{array}$ & $\begin{array}{c}48 \\
(41 \%)\end{array}$ & $\begin{array}{c}62 \\
(64 \%)\end{array}$ & $\begin{array}{c}232 \\
(54 \%)\end{array}$ & $\begin{array}{c}529 \\
(51 \%)\end{array}$ \\
\hline Economic issues & 68 & 35 & 196 & 205 & 504 \\
& $(59 \%)$ & $(36 \%)$ & $(45 \%)$ & $(52 \%)$ & $(49 \%)$ \\
\hline Total & 116 & 97 & 428 & 392 & 1033 \\
& $(100 \%)$ & $(100 \%)$ & $(100 \%)$ & $(100 \%)$ & $(100 \%)$ \\
\hline
\end{tabular}

2010, twelve firms were part of the Global Compact's "founding firms." Figure 1 shows when the sampled firms joined the Global Compact, if applicable. As the research design compares between the four indicated interest group types, the design, unfortunately, does not allow the inclusion of firm-level control variables in the main model, such as years of Global Compact membership. This, however, corresponds with the aim of the research to unfold differences between groups rather than trace causality.

To test robustness of the model, I cross validated binary Global Compact membership with reporting practices in accordance to the Global Reporting Initiative (GRI). The GRI is the largest private standard that aims to help firms understand and communicate their impact on "crucial sustainability" issues such as climate change and human rights. By re-running the models on another core CSR initiative, the generalizability of the results are strengthened. In other words, other types of soft law initiatives may yield similar differences. Keeping all other variables constant, results from the multivariate regression analysis showed no difference between GRI or Global Compact participation, nor were there any differences for firms participating in both initiatives or firms participating in one or the other. Appendix II reports the full regression tables.

\section{Intermediate variable: policy domain}

To control for the interaction effect with policy domains, I categorized proposals by their content, making use of the Comparative Agendas Project (CAP). This project classified policy activities into a single, universal and consistent coding scheme of nineteen policy areas divided into several subtopics. For each proposal the corresponding CAP code was determined and subsequently recoded into a binary variable. Economic issues include domestic commerce and foreign trade. Social and environmental issues include environment, health, immigration, technology, law \& crime, agricultural, transport, energy, and international affairs. This division was made based on the content and direction of the original policy proposals. Table 2 indicates that, in this sample, Global Compact signatory firms are, surprisingly, slightly more active in economic policy domains whereas non-signatory firms are slightly more active in social and ecological policy domains.

\section{Control variables}

To control for potential omitted variables that are correlated with, but not caused by interest group types, I check for various alternative explanations of policy preference. As the research design compares between the four indicated interest group types, all variables need to be applicable for all types of groups.

To start, policy preference might be affected the degree of unity or conflict between interest groups lobbying on the same issue. When actors share the same policy goal on a given issue, by default, they form an informal lobbying coalition. ${ }^{83}$ Unity is operationalized as the number of interest groups pulling in the same direction. ${ }^{84}$ The more unity, the more difficult it is to have an alternative policy

\footnotetext{
${ }^{83}$ Klüver 2013, 29.

${ }^{84}$ Dür et al. 2019.
} 
preference. Conflict, on the other hand, occurs when actors lobby on the same issue but explicitly state diverging preferences. ${ }^{85}$ The level of conflict between interest groups is operationalized as a standard deviation of interest groups' positions for each issue. The more conflict, the easier it is for firms to express an alternative preference.

Furthermore, public scrutiny may restrict firms' policy preference by making their lobbying efforts more visible. ${ }^{86}$ As such, media attention, operationalized as the logged number of reports within five selected newspapers, forces firms to take societal accepted policy preferences. Lastly, the better an actor is known for its technical knowledge, the easier they can use complexity and specialization to substantiate an alternative preference. ${ }^{87}$ Knowledge is operationalized as actors' issue intelligence as perceived by EU officials on a scale from one to five.

Although organizational-level factors cannot inform the main model, they can still be controlled for within the descriptive part of the analysis. ${ }^{88}$ Previous research has indicated that the factors that influence lobbying activities also largely determine participation in the Global Compact. ${ }^{89}$ As such, I build upon seminal work by Jackson and Apostolakou (2010) on the sectoral and national patterns of CSR adoption. They suggest that industry impact and varieties of capitalism (VOC) explain differences in CSR commitments. ${ }^{90}$

Firstly, sectoral data collected in accordance to the industry classification benchmark system shows that wholesale $(\mathrm{N}=26)$, finance $(\mathrm{N}=23)$, and electricity $(\mathrm{N}=17)$ are most prevalent in the INTEREURO sample overall. More specifically, signatory firms are most active in the electricity $(\mathrm{N}=12)$ and financial industries $(\mathrm{N}=11)$, whereas non-signatory firms are most active in the wholesale $(\mathrm{N}=18)$ and financial industries $(\mathrm{N}=12)$. Using the classification from Jackson and Apostolakou, I create a dummy variable for high versus medium-low (ecological) impact industries. High impact sectors include agriculture, construction, resources supply, manufacturing, transportation, and wholesale. Medium-low impact sectors include administration, entertainment, finance, insurance, social work, information, and science.

Secondly, data on firms' home-countries shows that the headquarters of the majority of signatory firms are based in France $(\mathrm{N}=11)$ and the UK $(\mathrm{N}=9)$, whereas the headquarters of non-signatory firms are mainly in the US $(\mathrm{N}=13)$ and UK $(\mathrm{N}=13)$. To control for VOC, firms based in the United Kingdom, the United States, or Israel were classified as liberal market economies (LMEs) and firms based in Austria, Belgium, Canada, Denmark, Finland, France, Germany, Italy, Luxembourg, Netherlands, Norway, Spain, Sweden, or Switzerland as coordinated market economies (CMEs).

\section{Results}

\section{Descriptive analysis}

To gain a better understanding of the data, I start by examining the median (ME) policy preferences of Global Compact signatory firms and non-signatory firms in the final sample relative to the median outcome, median reversion-point (RP), and median preferences of the EC, industry associations, and nonbusiness interest groups. Following the research design, all median preferences are policy proposal specific rather than firm specific; put differently, they correspond to lobbying activities on specific proposals and policy issues. The advantage of showing the median rather than the mean position is to prevent distortions from outliers. ${ }^{91}$

The results across all policy domains are spatially visualized in figure 2. Nonbusiness interest groups appear to lobby for maximal regulatory changes in the European Union. They preferred the greatest

\footnotetext{
${ }^{85}$ Chalmers 2018,5 .

${ }^{86}$ Chalmers and van den Broek 2019, 4.

${ }^{87}$ Eckert 2019, 6.

${ }^{88}$ Consult Appendix I for a further breakdown per industry and Appendix II for a further breakdown per home country.

${ }^{89}$ Bennie, Bernhagen, and Mitchell 2007.

${ }^{90}$ Note that all firms in the sample are considered "large firms," based on their average staff counts. Hence, this variable is not included as a firm-specific control variable.

${ }^{91}$ Dür et al. 2015.
} 


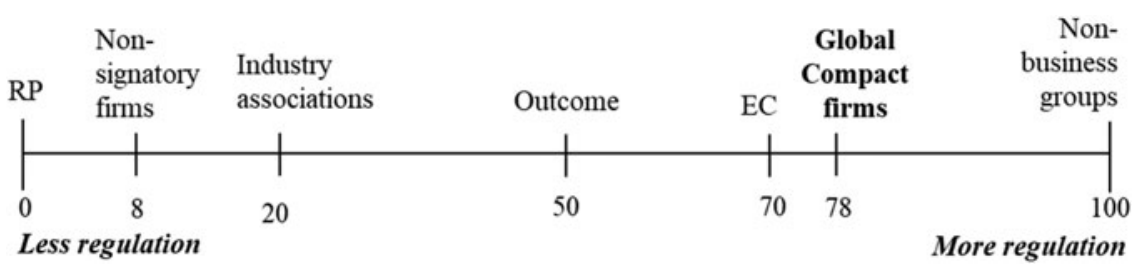

Figure 2: Median positions of actors, revision points (RP), and outcomes on all issues

Table 3: Mean policy preference stringency by policy domains

\begin{tabular}{lccc} 
& \multicolumn{2}{c}{ Policy domains } \\
\cline { 2 - 4 } & All domains & Economic & Social \& environmental \\
\hline Global Compact firms & 60.15 & 50.25 & 67.13 \\
\hline Non-signatory firms & 38.73 & 41.45 & 33.90 \\
\hline Industry associations & 39.27 & 43.62 & 34.12 \\
\hline Non-business groups & 70.55 & 66.53 & 74.21 \\
\hline EC & 68.14 & 73.28 & 62.42 \\
\hline EP & 70.35 & 68.00 & 73.36 \\
\hline Council & 50.50 & 53.52 & 43.91 \\
\hline Average & 53.43 & 52.07 & 54.87 \\
\hline
\end{tabular}

amount of legislation $(\mathrm{ME}=100)$ for 55 percent of the policy proposals. Industry associations $(\mathrm{ME}=$ 18) and non-signatory firms $(\mathrm{ME}=8)$, on the other hand, appear to lobby for the least amount of regulatory changes in the European Union, and are relatively close to the RP $(\mathrm{ME}=0)$. Industry associations lobbied 44 percent of the time for a continuation of the status-quo and non-signatory firms 47 percent of the time. Interestingly, Global Compact signatory firms $(\mathrm{ME}=78)$, prefer more stringent policies than the EC $(\mathrm{ME}=70)$ or the final outcome $(\mathrm{ME}=50)$. They lobbied for 41 percent of the time for the most stringent amount of regulatory change. ${ }^{92}$

The sample means $(\mathrm{x})$ of policy preference per interest group type, as shown in table 3, paint a similar picture. Industry associations $(x=39.27)$ and non-signatory firms $(x=38.73)$ prefer, on average, the lowest stringency of regulatory change. The majority of the EP $(x=70.35)$ and nonbusiness interest groups $(\mathrm{x}=70.55)$ prefer the highest stringency of regulatory change. Global Compact signatory firms' policy preferences $(x=60.15)$ fall between the mean preferences of majority of the Council $(x=50.50)$ and the EC $(\mathrm{x}=68.14)$. This is mirrored in the ordinal measurement of policy preference as well. The above provides preliminary, descriptive support for $\mathrm{H} 2$ and $\mathrm{H} 3$ : Global Compact signatory firms appear to prefer more stringent regulation than non-signatory firms and industry associations. However, $\mathrm{H} 1$ seems incorrect as nonbusiness interest groups still prefer the most stringent regulation.

To test for the moderating variable introduced in H4, I split the results into economic and social and environmental issues. For economic policy issues, there appears to be smaller differences within business groups. Median results show that non-signatory firms $(\mathrm{ME}=9)$ and industry associations $(\mathrm{ME}=33)$ prefer slightly more regulation for economic issues, whereas Global Compact signatory firms $(\mathrm{ME}=50)$ prefer much less regulation. For social and environmental issues, on the other

\footnotetext{
${ }^{92}$ These results are, however, more nuanced than the above suggests; the far-ends of the scale represent the two most common lobbying stringency categories. To illustrate, Global Compact firms lobbied for the lowest stringency of regulatory change $(\mathrm{P}=0)$ in 19 percent of the cases and firms' not participating with the Global Compact lobbied for the highest stringency of regulatory change $(\mathrm{P}=100) 30$ percent of the time.
} 
Table 4: Policy preference by Global Compact membership and industry impact

\begin{tabular}{llcr}
\hline & & \multicolumn{2}{c}{ Industry Impact } \\
\cline { 3 - 4 } & & High & Low \\
\hline \multirow{2}{*}{ Global Compact } & Signatory firms & 31.72 & 49.72 \\
& & $(\mathrm{~N}=27)$ & $(\mathrm{N}=22)$ \\
\cline { 2 - 4 } & Non-signatory firms & 55.37 & 70.17 \\
& & $(\mathrm{~N}=25)$ & $(\mathrm{N}=24)$ \\
\hline & Average & 43.10 & 60.39 \\
& & $(\mathrm{~N}=52)$ & $(\mathrm{N}=46)$ \\
\hline
\end{tabular}

Table 5: Policy preference by Global Compact membership and VOC

\begin{tabular}{llcr}
\hline & & \multicolumn{2}{c}{ Varieties of Capitalism } \\
\cline { 3 - 4 } & & LME & CME \\
\hline \multirow{2}{*}{ Global Compact } & Signatory firms & 67,61 & 60,83 \\
& & $(\mathrm{~N}=12)$ & $(\mathrm{N}=36)$ \\
\cline { 2 - 4 } & Non-signatory firms & 42,54 & 36,70 \\
& & $(\mathrm{~N}=26)$ & $(\mathrm{N}=23)$ \\
\hline & Average & 50.90 & 51.42 \\
& & $(\mathrm{~N}=39)$ & $(\mathrm{N}=59)$ \\
\hline
\end{tabular}

hand, results indicate a maximum widening of the gap within business group preferences. Industry associations and non-signatory firms prefer the continuation of the status quo ( $M E=0)$, whereas Global Compact signatory firms' preference align perfectly with nonbusiness interest groups in maximum regulatory change $(\mathrm{ME}=100)$. This result is mirrored by the means of policy preferences per policy domain, which can be found in the last two columns of table 3, providing preliminary, descriptive support for H4: The effect of the previous hypotheses appears stronger for social and environmental policy proposals.

Lastly, although firm-specific variables cannot inform the multivariate model, they are important descriptive indicators, allowing to control for firm-level differences that could explain the relationship between Global Compact membership and policy preference. Results indicate that firms are evenly distributed across industries, however, firms in high impact industries do have slightly lower preferences than firms in low impact industries (see table 4). Furthermore, there are relatively few Global Compact signatory firms from LMEs and more from CMEs (see table 5). Nevertheless, the policy preferences of firms from LMEs and CMEs are highly similar. Additionally, the direction of the effect remains similar in both cases: signatory firms prefer more regulation than non-signatory firms. ${ }^{93}$ These results are conferred by a simple two way Anova. Thus, firms' industry and home-country, appear to have no bearing on the results.

\section{Multivariate analysis}

I now turn to the multivariate regression analysis, for which I used a mixed effects linear regression analysis for the scale measurement of preference and a mixed effect ordered logistic regression for its ordinal equivalents. Groups are nested in proposals and issues and as such observations are dependent. Put differently, as some actors lobby on multiple issues, occasionally more than one measurement has been taken from the same actor. Therefore, I estimated hierarchical models with random effects at the proposal and issue levels.

\footnotetext{
${ }^{93}$ Note that these figures are informed by data on unique firms and, as such, reflect the average policy preference and classifies Global Compact membership by the cut-off year 2010 .
} 
Table 6: Multivariate Analysis

\begin{tabular}{|c|c|c|c|c|c|}
\hline & (1) & (2) & (3) & (4) & (5) \\
\hline & $\begin{array}{l}\text { Base } \\
\text { model }\end{array}$ & Preference & Preference & $\begin{array}{l}\text { Preference } \\
\quad \text { (ord) }\end{array}$ & $\begin{array}{l}\text { Preference } \\
\quad \text { (ord) }\end{array}$ \\
\hline Non-signatories & & $\begin{array}{l}-12.72^{\star \star} \\
(5.67)\end{array}$ & $\begin{array}{l}-7.38 \\
(7.48)\end{array}$ & $\begin{array}{c}0.26^{\star \star \star} \\
(0.05)\end{array}$ & $\begin{array}{c}0.41^{\star \star \star} \\
(0.10)\end{array}$ \\
\hline Industry associations & & $\begin{array}{c}-16.10^{\star \star \star} \\
(4.48)\end{array}$ & $\begin{array}{l}-6.61 \\
(6.88)\end{array}$ & $\begin{array}{c}0.24^{\star \star *} \\
(0.07)\end{array}$ & $\begin{array}{c}0.33^{\star \star *} \\
(0.12)\end{array}$ \\
\hline Non-business groups & & $\begin{array}{c}12.90^{\star \star \star} \\
(4.89)\end{array}$ & $\begin{array}{c}17.94^{\star \star \star} \\
(6.98)\end{array}$ & $\begin{array}{l}0.59^{\star} \\
(0.16)\end{array}$ & $\begin{array}{l}0.53^{*} \\
(0.58)\end{array}$ \\
\hline \multicolumn{6}{|l|}{ Group x Policy Domains } \\
\hline $\begin{array}{l}\text { Non-signatories, social \& } \\
\text { environ }\end{array}$ & & & $\begin{array}{l}-9.72 \\
(11.78)\end{array}$ & & $\begin{array}{c}0.30^{\star \star \star} \\
(0.12)\end{array}$ \\
\hline Association, social \& environ & & & $\begin{array}{c}-17.83^{\star \star} \\
(8.84)\end{array}$ & & $\begin{array}{l}0.37^{\star} \\
(0.22)\end{array}$ \\
\hline $\begin{array}{l}\text { Non-business, social \& } \\
\text { environ }\end{array}$ & & & $\begin{array}{l}-7.76 \\
(9.45)\end{array}$ & & $\begin{array}{c}0.99 \\
(0.52)\end{array}$ \\
\hline Conflict & $\begin{array}{c}-0.81^{\star \star \star} \\
(0.15)\end{array}$ & $\begin{array}{c}-0.67^{\star \star \star} \\
(0.15)\end{array}$ & $\begin{array}{l}-0.67^{\star * *} \\
(0.15)\end{array}$ & $\begin{array}{c}0.95^{\star \star *} \\
(0.01)\end{array}$ & $\begin{array}{l}0.95^{\star \star} \\
(0.01)\end{array}$ \\
\hline Side & $\begin{array}{l}-0.84 \\
(0.53)\end{array}$ & $\begin{array}{l}-0.11 \\
(0.52)\end{array}$ & $\begin{array}{l}-0.04 \\
(0.52)\end{array}$ & $\begin{array}{c}0.99 \\
(0.03)\end{array}$ & $\begin{array}{l}1.00 \\
(0.03)\end{array}$ \\
\hline Media Attention & $\begin{array}{c}4.80 \\
(3.41)\end{array}$ & $\begin{array}{c}4.16 \\
(3.25)\end{array}$ & $\begin{array}{c}3.72 \\
(3.25)\end{array}$ & $\begin{array}{c}1.30 \\
(0.27)\end{array}$ & $\begin{array}{c}1.25 \\
(0.26)\end{array}$ \\
\hline IG Knowledge & $\begin{array}{l}-2.42^{\star} \\
(-1.73)\end{array}$ & $\begin{array}{l}-2.15 \\
(1.38)^{\star \star \star}\end{array}$ & $\begin{array}{l}-2.27 \\
(1.39)\end{array}$ & $\begin{array}{l}0.84^{\star *} \\
(0.07)\end{array}$ & $\begin{array}{l}0.84^{\star *} \\
(0.07)\end{array}$ \\
\hline Constant & $\begin{array}{c}81.94^{\star \star \star} \\
(11.97)\end{array}$ & $\begin{array}{c}77.18^{\star \star \star} \\
(12.70)\end{array}$ & $\begin{array}{c}74.17^{\star \star \star} \\
(14.04)\end{array}$ & & \\
\hline Observations & 937 & 937 & 937 & 937 & 937 \\
\hline $\mathrm{N}$ proposals & 67 & 67 & 67 & 67 & 67 \\
\hline $\mathrm{N}$ issues & 108 & 108 & 108 & 108 & 108 \\
\hline Variance (proposals) & 17.60 & 16.16 & 15.99 & 1.14 & 1.19 \\
\hline Variance (issues) & 9.49 & 10.57 & 10.49 & 0.45 & 0.43 \\
\hline
\end{tabular}

Exponentiated coefficients; odds ratio; $t$ statistics in parentheses ${ }^{*} \mathrm{p}<0.1,{ }^{* *} \mathrm{p}<0.05,{ }^{* * *} \mathrm{p}<0.01$

Table 6 summarizes the results, taking Global Compact signatory firms as the base category. Model 1 shows the base model, excluding interest group types, and indicates that only the control variables "conflict" and "knowledge" are significant. Looking at model 2, the coefficients for non-signatory firms, as well as industry associations, are negative and statistically highly significant, indicating that Global Compact signatory firms prefer higher levels of regulatory change than other business actors. The coefficient for nonbusiness interest groups, on the other hand, is positive and also highly significant implying that this interest group type still lobby for more regulatory change than Global Compact signatory firms. The marginal odds of these results are visualized in figure 3.

Model 4 shows that these effects are substantial; using the ordinal measure of policy preference does not alter the overall results, even though the significance level of non-business interest groups slightly decreases. Thus, the multivariate results mirror the descriptive analysis and provide statistically strong support for $\mathrm{H} 2$ and H3: Firms participating in the Global Compact lobby significantly for higher levels of regulatory change compared to non-signatory firms and industry associations. There is, on the other hand, little support for $\mathrm{H} 1$ : Although Global Compact signatory firms' regulatory preferences are more 


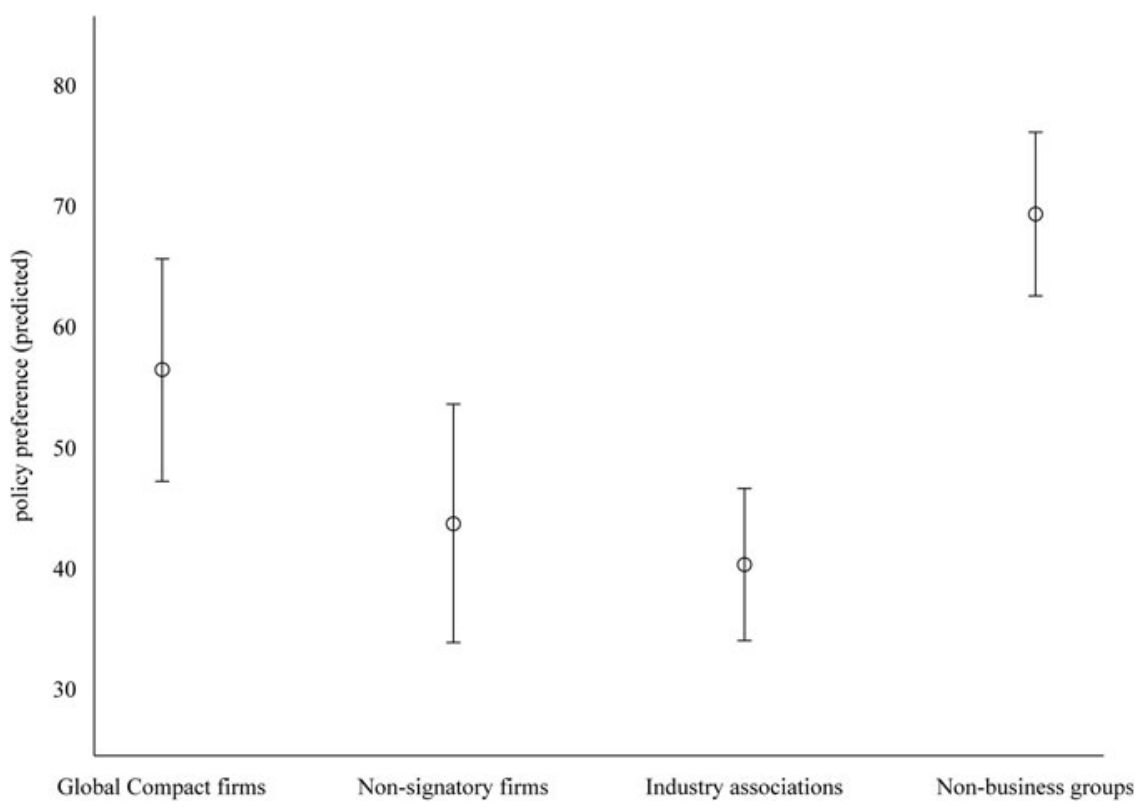

Figure 3: Marginal odds for policy preferences, by interest group types

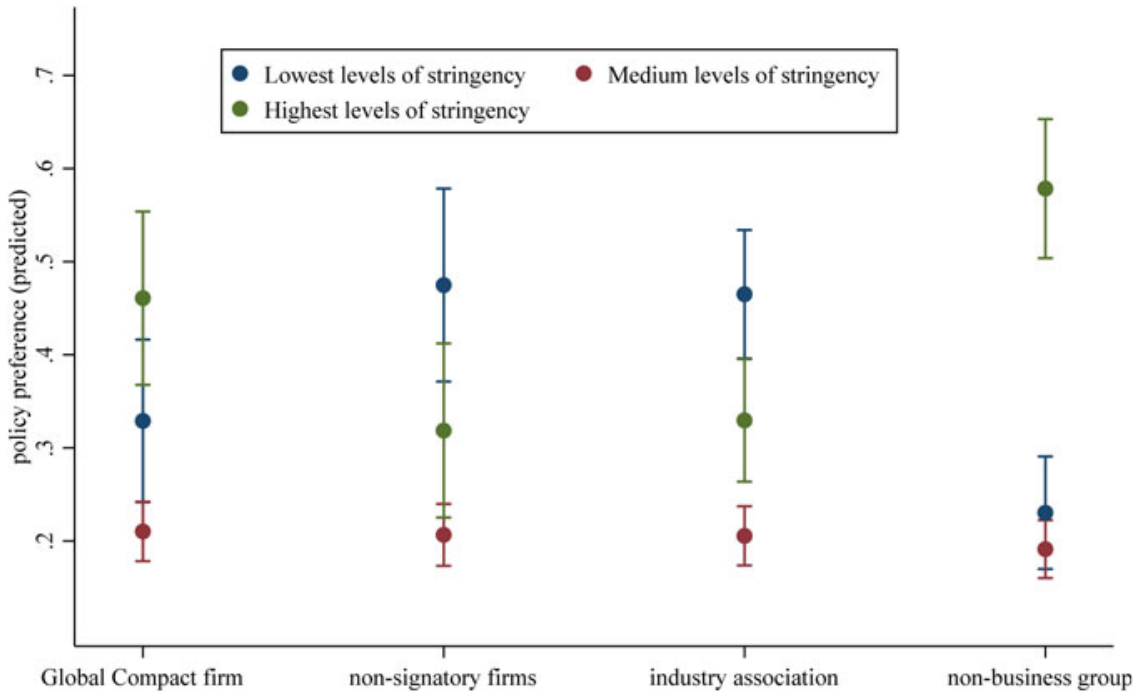

Figure 4: Marginal odds for policy preference, by policy domain and interest group types

aligned with nonbusiness than with business groups, they still prefer significantly less regulatory stringency.

Model 3 adds the interaction term between interest group types and policy domains to test whether the effect of interest group type on policy preference is conditional on the policy domain. The results show that the coefficients for the interaction term are only negatively, statistically significant for industry associations.

Model 5 shows that this effect is still substantial when using the ordinal measure of policy preference, even though the significance level decreases slightly. Additionally, using the ordinal measure unveils a significant, negative coefficient for non-signatory firms. Figure 4 illustrates the interaction effect on the ordinal measurement for policy preference, while keeping all other variables constant. 
These mixed results lead to a partial acceptance of $\mathrm{H} 4$ : The difference in regulatory preference between Global Compact signatory firms and industry associations is slightly larger for social and environmental issues than for economic issues; this effect, however, is weak.

\section{Discussion and conclusion}

This study demonstrated that Global Compact signatory firms support more stringent supranational regulation than non-signatory firms. How does this relate to work previously featured in Business and Politics? To start, my findings empirically amplify Gjølberg's assertion that firms engaged in CSR initiatives are favorable toward hard law interventions. However, our results deviate in terms of the direction of the relationship between soft and hard law; whereas Gjølberg argues that firms engaged in CSR initiatives are skeptical toward soft law arrangements, my findings suggest that that rather than being substitutes, CSR and soft law initiatives complement binding regulation. ${ }^{94}$ Future research should shed further light on this dynamic interaction and may build further on Gjølberg's survey results and shed more light on managerial motivations behind stricter regulatory preferences, which appear to be shaped by competitive institutional advantages. ${ }^{95}$ Furthermore, although my results seemingly refute Kinderman's arguments, they could well co-exist due to the different types of operationalization. To explain, whereas this study specifically looked at firm-level regulatory support, Kinderman primarily focused on country-level regulatory support. ${ }^{96}$ As such, it could be that although CSR affects the policy positions of individual firms, it does not explain countries' preferences for EU regulation at an aggregated level. Future research should further scrutinize the relationship, and tensions, between the two.

Interestingly, the results of this analysis indicated that the effect of policy domains as a moderating variable was very weak and only significant across all models for industry associations. Future research should further examine if, as well as how and why, this effect varies for different policy issues, and ultimately, what this means for the CSR concept. Two explanations bear further scrutiny. Firstly, there has been a growing awareness of the integrated nature between economic, social, and environmental issues. This is illustrated by the agenda stipulated in the Sustainable Development Goals (SDGs), which incorporates environmental, social, and economic sustainability. ${ }^{97}$ Hence, the division between policy domains may be rather artificial. Secondly, the policy proposals within the sample were put forward in the immediate aftermath of the recent global financial crisis. Since regulatory failure was at the root of the crisis, and large firms were largely held responsible, ${ }^{98}$ promoting more stringent economic regulation may have been part of firms' broader societal responsibility during this period. Future research should, additionally, expand mediating and moderating variables, most importantly, by focusing solely on individual firm lobbying and firm-specific variables, such as industry, homecountry, and size.

Examining how signatory and non-signatory firms are politically different is crucial in understanding the relationship between Global Compact membership and hard law. ${ }^{99}$ My results are particularly telling since the Global Compact is on the "weak-side" of the CSR spectrum. Future research should further examine the direction of causality between Global Compact membership and regulatory preferences. This could theoretically be explained in two ways: Either signatory firms were already different before they joined the Global Compact, or they changed after joining. The first explanation would yield important conclusions for the question "who becomes a member?" as it counters the criticism of "adverse selection" put forward by Sethi and Schepers. The second explanation, on the other

\footnotetext{
${ }^{94}$ For an overview of the discussion on whether soft and hard law are substitutes or complements, see Kirton and Trebilcock (2017).

${ }^{95}$ Gjølberg 2011, 2; A similar argument was put forward by Fremeth and Richter (2011).

${ }^{96}$ Kinderman 2019, 30 .

${ }^{97}$ Fukuda-Parr 2016, 48.

${ }^{98}$ Chalmers and van den Broek 2019.

${ }^{99}$ Rasche and Waddock 2014, 214.
} 
hand, would yield critical insights for the question "what does membership effectuate?" as it provides support for the underlying learning mechanisms put forward by Williams as well as Rasche and Waddock. ${ }^{100}$ Future research could study a smaller subset of firms over a longer period of time and inductively trace the process of how these firms change their behavior after joining a principle-based CSR institution.

This study aimed to enrich the larger soft and hard law debate with insights in corporate policy preferences. ${ }^{101}$ Shaped by the larger neoliberal context, ${ }^{102}$ this debate touches upon political views on the appropriate role of the state in society and the economy ${ }^{103}$ and is tightly linked to ideology. ${ }^{104}$ My results indicated that CSR soft law initiatives do not only fill in governance gaps left by national governments, ${ }^{105}$ but that they may also yield important consequences for hard law interventions. My observation that firms' participating in a soft law initiative prefer more stringent regulation, provides an alternative reality to Vogel's well-known argument that firms participate in soft law arrangement with the aim to avoid stricter hard laws. ${ }^{106}$ Put differently, greater soft law does not necessarily imply less hard law, on the contrary, the two appear to complement and support each other. To better understand how firms' policy preferences result in hard law regulatory changes, future research could further scrutinize the lobbying success of firms that engage in soft law CSR institutions ${ }^{107}$ as well as examine different regulatory contexts and soft law initiatives. This line of inquiry would add to the emerging literature of co-regulation, and private-public regulatory partnerships and coalitions. ${ }^{108}$

Lastly, the comparative research design of this analysis allowed for a contrast between signatory and non-signatory firms with industry associations and nonbusiness groups based on their spatial preferences for regulatory change. As such, my data measured alignment between business and nonbusiness interests, warranting inferences about how certain firms may promote stakeholders' interests. My results demonstrated that Global Compact signatory firms are significantly different from industry associations, which, similar to non-signatory firms, push for a regulatory race to the bottom. However, they are also different from nonbusiness interest groups, which push for a regulatory race the top. Nevertheless, Global Compact signatory firms are still more aligned with nonbusiness groups, and as such, with the stakeholders' interest. Future research should further explore whether, and how, this could provide a buffer against "elitism" and interest group distortions of the functioning of democracies. ${ }^{109}$ This may also shed more light on the outliers and the clustering of firms' policy preferences around the two far-ends of the regulatory preference spectrum, either preferring no regulatory change $(\mathrm{P}=0)$ or maximum regulatory change $(\mathrm{P}=100)$.

Acknowledgements. This research benefitted from support from the Economic and Social Research Council (ESRC). Feedback provided at the "Alliance for Research on Corporate Sustainability" held in 2020 and "European Consortium for Political Research" held in 2019, on an early draft, proved instructive in shaping the theoretical arguments. The author would like to thank the INTEREURO group, and in particular Andreas Dür, Patrick Bernhagen, and David Marshall, for sharing their database, as well as Adam Chalmers, Kathleen Rehbein, and Jeremy Moon for their constructive suggestions on a previous version. Finally, my thanks to the two anonymous reviewers who helped improve this manuscript.

\footnotetext{
${ }^{100}$ Rasche and Waddock 2014; Sethi and Schepers 2014; Williams 2014. See also Berliner and Prakash 2014; Voegtlin and Pless 2014; Schembera 2018.

${ }^{101}$ Abbott and Snidal 2000; Kirton and Trebilcock 2017; Rasche 2015; Schrempf-Stirling 2018; Shaffer and Pollack 2009.

${ }^{102}$ Neoliberalism, arguably, commenced with the work of Hayek and the establishment of the Mont Pelerin Society after the Second World War.

${ }^{103}$ Dashwood 2017, 196.

${ }^{104}$ Llewellyn 2007, 177; In terms of partisan politics, this implies that left-center parties tend to support more business legislation whereas right-center parties tend to favor industries to regulate themselves.

${ }^{105}$ Schrempf-Stirling 2018, 3.

${ }^{106}$ Vogel 2008.

${ }^{107}$ This could be done based on the INTEREURO data, or alternatively the methodology, on lobbying success, which is measured as how much an actor is able to pull the policy outcome in their preferred direction.

${ }^{108}$ Schrempf-Stirling 2018; Knudsen, Moon and Rieneke 2015.

${ }^{109}$ Wright Mills 1956; Dahl 1961.
} 


\section{References}

BP. 2018. "Sustainability Report.” www.unglobalcompact.org/participation/report/cop/create-and-submit/active/427784.

Abbott, Kenneth W., and Duncan Snidal. 2000. "Hard and soft law in international governance." International organization 54 (3): 421-56.

AccountAbility and Global Compact. 2005. “Towards Responsible Lobbying.” www.unglobalcompact.org/library/254.

Anastasiadis, Stephanos. 2014. "Toward a view of citizenship and lobbying: Corporate engagement in the political process" Business \& Society 53 (2): 260-99.

Barnett, Michael L. 2013. “One voice, but whose voice? Exploring what drives trade association activity.” Business \& Society 52 (2): 213-44.

Barnett, ML, I Henriques, and BW Husted. 2020. "Beyond good intentions: Designing CSR initiatives for greater social impact." Journal of Management 46 (6): 937-964.

Bartley, Tim. 2018. "Transnational Corporations and Global Governance." Annual Review of Sociology 44: 145-65.

Bennie, Lynn, Patrick Bernhagen, and Neil J. Mitchell. 2007. "The logic of transnational action: The good corporation and the Global Compact." Political Studies 55 (4): 733-53.

Berliner, Daniel, and Aseem Prakash. 2014. "The United Nations global compact: An institutionalist perspective.” Journal of Business Ethics 122 (2): 217-23.

Berliner, Daniel, and Aseem Prakash. 2015. "Bluewashing the Firm? Voluntary Regulations, Program Design, and Member Compliance with the United Nations G lobal Compact." Policy Studies Journal 43 (1): 115-38.

Bernhagen, Patrick, Neil J. Mitchell, and Marianne Thissen-Smits. 2013. "Corporate citizens and the UN Global Compact: Explaining cross-national variations in turnout." Business and Politics 15 (1): 63-85.

Beyers, Jan, Rainer Eising, and William Maloney. 2008. "Researching interest group politics in Europe and elsewhere: much we study, little we know?” West European Politics 31 (6): 1103-28.

Beyers, Jan, Andreas Dür, David Marshall, and Arndt Wonka. 2014. "Policy-centred sampling in interest group research: Lessons from the INTEREURO project.” Interest Groups \& Advocacy 3 (2): 160-73.

Bouwen, Pieter. 2004. "Exchanging access goods for access: A comparative study of business lobbying in the European Union institutions." European Journal of Political Research 43 (3): 337-69.

Brammer, Stephen, Gregory Jackson, and Dirk Matten. 2012. "Corporate social responsibility and institutional theory: New perspectives on private governance." Socio-economic Review 10 (1): 3-28.

Chalmers, Adam W. 2018 "Unity and conflict: Explaining financial industry lobbying success in European Union public consultations." Regulation \& Governance.

Chalmers, Adam W., and Onna M. van den Broek 2019. "Financial volatility and public scrutiny as institutional determinants of financial industry firms' CSR.” Business and Politics 21 (2): 240-66.

Chalmers, Adam W., and Keving L. Young 2020. "Network effects in the formation of the financial industry's regulatory preferences in the European Union." Business and Politics 22 (1): 52-84.

Coen, David. 1998. "The European business interest and the nation state: large-firm lobbying in the European Union and member states." Journal of Public Policy: 75-100.

Conzelmann, Thomas. 2012. "A procedural approach to the design of voluntary clubs: Negotiating the responsible care global charter." Socio-Economic Review 10 (1): 193-214.

Dahl, Robert A. 1961. Who governs?: Democracy and power in an American city. New Haven, CT: Yale University Press.

Dashwood, Hevina S. 2017. "Corporate Social Responsibility and the Evolution of International Norms" In Hard choices, soft law: Voluntary standards in global trade, environment and social governance, edited by John J. Kirton and Michael J. Trebilcock. New York: Routledge.

De Bakker, Frank GA, Andreas Rasche, and Stefano Ponte. 2019. "Multi-Stakeholder initiatives on sustainability: a crossdisciplinary review and research agenda for business ethics." Business Ethics Quarterly 29 (3): 343-83.

Den Hond, Frank, Kathleen A. Rehbein, Frank GA de Bakker, and Hilde Kooijmans-van Lankveld. 2014. "Playing on two chessboards: Reputation effects between corporate social responsibility (CSR) and corporate political activity (CPA)." Journal of management studies 51 (5): 790-813.

DiMaggio, Paul J., and Walter W. Powell. 1983. "The iron cage revisited: Institutional isomorphism and collective rationality in organizational fields." American sociological review: 147-60.

Dür, Andreas. 2008. "Measuring interest group influence in the EU: A note on methodology." European Union Politics 9 (4): $559-76$.

Dür, Andreas, Patrick Bernhagen, and David Marshall. 2015. "Interest group success in the European Union: When (and why) does business lose?" Comparative Political Studies 48 (8): 951-83.

Dür, Andreas, Dave Marshall, and Patrick Bernhagen. 2019. “The Political Influence of Business in the European Union.” Ann Arbor, MI: University of Michigan Press.

Eckert, Sandra. 2019. "Corporate Power and Regulation: Consumers and the Environment in the European Union." London: Palgrave Macmillan.

Favotto, Alvise, and Kelly Kollman. 2019. "Mixing business with politics: Does corporate social responsibility end where lobbying transparency begins?” Regulation \& Governance: doi.org/10.1111/rego.12275.

Freeman, Gary P. 1985. "National styles and policy sectors: Explaining structured variation.” Journal of Public Policy 5 (4): 467-96.

Fremeth, Adam R., and Brian K. Richter. 2011. "Profiting from environmental regulatory uncertainty: Integrated strategies for competitive advantage." California Management Review 54 (1): 145-65. 
Fukuda-Parr, Sakiko. 2016. "From the Millennium Development Goals to the Sustainable Development Goals: shifts in purpose, concept, and politics of global goal setting for development." Gender \& Development 24 (1): 43-52.

Gjølberg, Maria. 2011. "Explaining regulatory preferences: CSR, soft law, or hard law? Insights from a survey of Nordic pioneers in CSR.” Business and Politics 13 (2): 1-31.

Hillman, Amy J., Gerald D. Keim, and Douglas Schuler. 2004. "Corporate political activity: A review and research agenda." Journal of Management 30 (6): 837-57.

Influence Map. 2020. "How bug oil continues to oppose the Paris Agreement." https://influencemap.org/report/How-Big-OilContinues-to-Oppose-the-Paris-Agreement.

Jackson, Gregory, and Androniki Apostolakou. 2010. “Corporate social responsibility in Western Europe: An institutional mirror or substitute?” Journal of business ethics 94 (3): 371-94.

Karr, Karolina. 2007. "Democracy and lobbying in the European Union." Germany: Campus Verlag.

Kell, Georg, and John Gerard Ruggie. 1999. "Global markets and social legitimacy: The case of the Global Compact." Transnational corporations 8 (3): 101-20.

Kinderman, Daniel. 2016 "Time for a reality check: Is business willing to support a smart mix of complementary regulation in private governance?" Policy and Society 35 (1): 29-42.

Kinderman, Daniel. 2019. "The tenuous link between CSR performance and support for regulation: Business associations and Nordic regulatory preferences regarding the corporate transparency law 2014/95/EU.” Business and Politics: 1-36.

Kirton, John J., and Michael J. Trebilcock. 2017. "Hard choices, soft law: Voluntary standards in global trade, environment and social governance." New York: Routledge.

Klüver, Heike. 2013. Lobbying in the European Union: Interest Groups, Lobbying Coalitions, and Policy Change. Oxford: Oxford University Press.

Knudsen, Jette S., Jenny Moon, and Rieneke Slager. 2015. “Government policies for corporate social responsibility in Europe: A comparative analysis of institutionalisation.” Policy \& Politics 43 (1): 81-99.

Liedong, Tahiru Azaaviele, Abby Ghobadian, Tazeeb Rajwani, and Nicholas O’Regan. 2015. "Toward a view of complementarity: trust and policy influence effects of corporate social responsibility and corporate political activity." Group \& Organization Management 40 (3): 405-27.

Lindblom, Charles. E. 1980. The policy-making process. Englewood Cliffs, NJ: Prentice-Hall.

Llewellyn, John. 2007. "Government, business, and the self in the United States." In The debate over corporate social responsibility, edited by Steven K. May, George Cheney, and Juliet Roper. Oxford: Oxford University Press.

Lock, Irina, and Peter Seele. 2016 "Deliberative lobbying? Toward a noncontradiction of corporate political activities and corporate social responsibility?" Journal of Management Inquiry 25 (4): 415-30.

Lyon, Thomas P., Magali A. Delmas, John W. Maxwell, Pratima Bansal, et al. 2018. "CSR needs CPR: Corporate sustainability and politics." California Management Review 60 (4): 5-24.

Martin, Cathie J. 1995. "Nature or nurture? Sources of firm preference for national health reform." American Political Science Review: 898-913.

Matten, D, and J Moon. 2008. "Implicit' and 'explicit' CSR: A conceptual framework for a comparative understanding of corporate social responsibility.” Academy of Management Review 33 (2): 404-24.

Mills Wright, C. 1956. The Power Elite. New York: Oxford University Press.

Olson, Mancur. 1965. "The Logic of Collective Action.” Cambridge: Cambridge University Press.

Rasche, Andreas. 2015. "The corporation as a political actor-European and North American perspectives." European management journal 33 (1): 4-8.

Rasche, Andreas, and Sandra Waddock. 2014. "Global sustainability governance and the UN Global Compact: A rejoinder to critics." Journal of Business Ethics 122 (2): 209-16.

Rivoli, Pietra, and Sandra Waddock. 2011. " 'First they ignore you . . '.: The time-context dynamic and corporate responsibility.” California Management Review 53 (2): 87-104.

Ruggie, John Gerard. 2007. "Business and human rights: the evolving international agenda." American Journal of International Law 101 (4): 819-40.

Ruggie, John Gerard. 2018. "Multinationals as global institution: Power, authority and relative autonomy." Regulation and Governance 12 (3): 317-33.

Schembera, Stefan. 2018. "Implementing corporate social responsibility: Empirical insights on the impact of the UN Global Compact on its business participants." Business and Society 57 (5): 783-825.

Schmitter, Philippe C., and Wolfgang Streeck. 1999. "The organization of business interests: Studying the associative action of business in advanced industrial societies." MPIfG discussion paper, 9/11.

Schrempf-Stirling, Judith. 2018. "State power: Rethinking the role of the state in political corporate social responsibility." Journal of Business Ethics 150 (1): 1-14.

Sethi, S. Prakash, and Donald H. Schepers. 2014. "United Nations global compact: The promise-performance gap." Journal of Business Ethics 122 (2): 193-208.

Shaffer, Gregory C., and Mark A. Pollack. 2009. "Hard vs. soft law: Alternatives, complements, and antagonists in international governance.” Minnesota Law Review 94: 706-800.

Truman, David B. 1951. “The governmental process: Political interests and public opinion.” New York: Alfred A. Knopf. 
van den Broek, Onna, Adam Chalmers, and Alfio Puglisi. 2020. "Interest Groups." In The Palgrave Encyclopedia of Interest Groups, Lobbying and Public Affairs, edited by Harris P., Bitonti A., Fleisher C., and A. Skorkjær Binderkrantz. London: Palgrave Macmillan.

Visser, Wayne. 2010. "The age of responsibility: CSR 2.0 and the new DNA of business." Journal of business systems, governance and ethics 5 (3).

Voegtlin, Christian, and Nicola M. Pless. 2014. "Global governance: CSR and the role of the UN Global Compact.” Journal of Business Ethics 122 (2): 179-91.

Vogel, David. 2008. "Private global business regulation.” Annual Review of Political Science 11: 261-82.

Wang, Heli, and Cuili Qian. 2011. "Corporate philanthropy and corporate financial performance: The roles of stakeholder response and political access." Academy of Management Journal 54 (6): 1159-81.

Wettstein, Florian, and Dorothea Baur. 2016. “"Why should we care about marriage equality?": Political advocacy as a part of corporate responsibility." Journal of business ethics 138 (2): 199-213.

Williams, Oliver F. 2014. “The United Nations global compact: What did it promise?" Journal of business ethics 122 (2): $241-51$. 


\section{Appendix I}

a. Overview firm's country of origin

\begin{tabular}{lcc}
\hline Country of origin & Global Compact signatory firms (N) & Non-signatory firms (N) \\
\hline Austria & 1 & 0 \\
\hline Belgium & 0 & 2 \\
\hline Canada & 0 & 1 \\
\hline Denmark & 0 & 1 \\
\hline Finland & 1 & 0 \\
\hline France & 11 & 0 \\
\hline Germany & 7 & 9 \\
\hline Israel & 1 & 0 \\
\hline Italy & 3 & 3 \\
\hline Luxembourg & 0 & 1 \\
\hline Netherlands & 4 & 0 \\
\hline Norway & 3 & 0 \\
\hline Spain & 2 & 3 \\
\hline Sweden & 1 & 1 \\
\hline Switzerland & 3 & 1 \\
\hline UK & 9 & 13 \\
\hline USA & 3 & 3 \\
\hline
\end{tabular}

b. Overview firms' sector according to the Economic Classification of Economic Activities (NACE)

\begin{tabular}{lcc}
\hline Industry & Global Compact signatory firms (N) & Non-signatory firms (N) \\
\hline Administrative and support service activities & 0 & 1 \\
\hline Agriculture, forestry and fishing & 0 & 1 \\
\hline Arts, entertainment and recreation & 0 & 4 \\
\hline Construction & 0 & 1 \\
\hline Electricity, gas, steam and air conditioning supply & 12 & 5 \\
\hline Financial and insurance activities & 11 & 12 \\
\hline Human health and social work activities & 5 & 0 \\
\hline Information and communication & 5 & 3 \\
\hline $\begin{array}{l}\text { Manufacturing } \\
\text { Professional, scientific and technical activities }\end{array}$ & 4 & 1 \\
\hline Transportation and storage & 2 & 2 \\
\hline $\begin{array}{l}\text { Wholesale and retail trade; repair of motor } \\
\text { vehicles and motorcycles }\end{array}$ & 1 & 1 \\
\hline
\end{tabular}




\section{Appendix II}

To test the robustness of the regression models, I created three alternative measurements of firm participation in a CSR institution. I started with coding for each company whether they disclosed nonfinancial information through the GRI framework one year prior to their specific lobbying effort. Subsequently, I created two new variable combining Global Compact membership and GRI disclosure: one variable requiring engagement in both CSR initiatives and another variable requiring engagement in only one of the two CSR initiatives. Similar to the original models, I created four groups, kept the preference as a ratio measurement and included all control variables. Model 1 in Table $\mathrm{x}$ shows the results for firms which reported through the GRI framework as the base category. Model 2 shows the results for firms which either reported through the GRI framework or were a member of the Global Compact as the base category; and model 3 shows the results for firms which both reported through the GRI framework and were a member of the Global Compact. The results for all three alternative measures appear not to divert from the original model, if anything, the results are stronger and more significant. Hence, I conclude that the model is indeed robust.

Table x: Robustness tests

\begin{tabular}{|c|c|c|c|c|}
\hline & & $\begin{array}{c}\text { (1) } \\
\text { preference }\end{array}$ & $\begin{array}{c}\text { (2) } \\
\text { preference }\end{array}$ & $\begin{array}{c}\text { (3) } \\
\text { preference }\end{array}$ \\
\hline \multirow[t]{6}{*}{ GRI } & Other Firms & $-29.59^{\star \star \star}$ & & \\
\hline & & (3.38) & & \\
\hline & Associations & $-21.37^{\star \star \star}$ & & \\
\hline & & (5.19) & & \\
\hline & Non-Business & $16.01^{\star \star \star}$ & & \\
\hline & Groups & (5.05) & & \\
\hline GRI or Global & Other Firms & & $-10.34^{\star}$ & \\
\hline \multirow[t]{5}{*}{ Compact } & & & $(5.86)$ & \\
\hline & Associations & & $-14.91^{\star \star \star}$ & \\
\hline & & & $(4.35)$ & \\
\hline & Non-Business & & $14.63^{\star \star \star}$ & \\
\hline & Groups & & $(4.80)$ & \\
\hline GRI and Global & Other Firms & & & $-11.74^{\star \star}$ \\
\hline \multirow[t]{11}{*}{ Compact } & & & & $(5.85)$ \\
\hline & Associations & & & $-17.95^{\star \star \star}$ \\
\hline & & & & (5.10) \\
\hline & Non-Business & & & $11.65^{\star \star}$ \\
\hline & Groups & & & $(5.48)$ \\
\hline & Interest group & $-.89^{\star \star \star}$ & $-.88^{\star \star \star}$ & $-.89^{\star \star \star}$ \\
\hline & conflict & (.17) & $(.17)$ & $(.17)$ \\
\hline & side & -.69 & -.69 & -.69 \\
\hline & & $(.52)$ & (.52) & $(.52)$ \\
\hline & Log total & $5.78^{\star \star}$ & $5.71^{\star \star}$ & $5.84^{\star \star}$ \\
\hline & media & $(2.89)$ & $(2.88)$ & $(2.89)$ \\
\hline
\end{tabular}


Table x: (Continued.)

\begin{tabular}{lccc}
\hline & $(1)$ & $(2)$ & $(3)$ \\
preference & preference & $-2.76^{\star}$ & $-2.67^{\star}$ \\
\hline Interest group & $-2.66^{\star}$ & $(1.41)$ & $(1.41)$ \\
\hline knowledge & $(1.42)$ & $86.58^{\star \star \star}$ & $89.55^{\star \star \star}$ \\
\hline Constant & $101.34^{\star \star \star}$ & $(12.38)$ & $(12.65)$ \\
\hline & $(11.43)$ & 873 & 873 \\
\hline Variance (proposals) & 873 & 12.53 & 12.65 \\
\hline Variance (issues) & 12.71 & 10.13 & 10.01 \\
\hline Log Likelihood & 9.98 & -4460.64 & -4460.18 \\
\hline
\end{tabular}

Exponentiated coefficients; $\mathrm{t}$ statistics in parentheses

${ }^{\star} p<0.1,{ }^{\star \star} p<0.05,{ }^{\star \star *} p<0.01$

Cite this article: van den Broek O (2021). Soft Law Engagements and Hard Law Preferences: Comparing EU Lobbying Positions between UN Global Compact Signatory Firms and Other Interest Group Types. Business and Politics 23, 383-405. https:// doi.org/10.1017/bap.2021.2 